274 CT検査における被ばく線量の低減を目的とした非線形量子 ノイズ低隇フィルタの開発一アルゴリズムの改良一 広島市立広島市民病院・放射線科，広島国際大学大学院・総合人間科学 研究科医療工学専攻 西丸英治

広島市立広島市民病院·放射線科砂森 浩，釜須広行，二野宮祐司 尾野 裕

広島国際大学大学院 ·総合人間科学研究科医療工学専攻 石田隆行 【目的】第60回総会学術大会において，非線形量子ノイズ低減フィル 夕の開発㧍よびフィル夕の特性, 効果を報告した。問題点として, ピクセルサイズに依存してフィルタの効果が十分に得られない場合 があった。 そこで今回我々は，この問題点の改善を目的として，抽 出したピクセル值に重み付けを行うことを考案し，それぞれの重み 付け関数について物理特性およびノイズ低減効果を検討した。

【使用機器】CT装置：Light Speed Ultra 8DAS(GEYMS), ファント ム: Catphan(Phantom Laboratory)，QAファントム (GEYMS) 【方法】今回 4 つのタイプ(A，B，C，D）の重み付け関数を作成し, その物理特性と効果を検討する。物理特性の検討項目は, Axial画像 面の解像度特性, ノイズ特性であり, 新旧のフィル夕処理画像と腹 部標準関数画像を比較した。また，第二報で十分なフィルタ効果が 得られなかったFOV (field of view) $30 \mathrm{~cm}$ について, 適切な重み関数の タイプを選択し，ノイズ低減効果を検討した．検討方法は，第二報 と同様な方法で定量的，視覚的に行った．最後にフィル夕処理前と フィルタ処理後の被ばく線量の低減効果を検討した。

【結果】解像度特性はB夕イプ，ノイズ特性はDタイプが優れていた。 物理特性㧍よび視覚的な総合評価の結果，B夕イプの重み関数が最 も優れていた。

【結語】今回作成した重み付け関数を新たにアルゴリズムに加えるこ とで, FOV $30 \mathrm{~cm}$ の被ばく線量の低減効果は $10 \%$ 向上した。

\section{6 列MDCTに扔ける量子ノイズ除去フィルタの検討} 虎の門病院·放射線部 渋谷清和, 吉原千治, 多賀谷靖, 勝又清一 鈴木 斉，田野政勝，辻 良憲

【目的】16列MDCTにおいて画像再構成により元のスライス厚より薄 いスライスに容易に再構成を行うことが可能であるが，ノイズ成分 の多い画像になる。そこで今回低被ばく線量における画質向上をは かるために開発された量子ノイズ除去フィル夕を用いその有用性に ついて検討した。

【方法】水ファントムを検出器構成 $1 \mathrm{~mm} \times 16$ 列, 管電流はReal ECを 用い再構成画像が10mmでSD8 の設定にて撮影を行った．その画像 より $5 \mathrm{~mm}, 3 \mathrm{~mm}, 1 \mathrm{~mm}$ 厚の画像を再構成し, 元画像と量子ノイ ズ除去フィルタを用いた画像のSDを測定し比較検討した。

【結果】元画像に対し量子ノイズ除去フィル夕を用いたことで水ファ ントム画像 $5 \mathrm{~mm}, 3 \mathrm{~mm}, 1 \mathrm{~mm}$ 各画像に执いて 26 30\%SDの向上 が認められた。 また腹部臨床画像においても $5 \mathrm{~mm}, 3 \mathrm{~mm}, 1 \mathrm{~mm}$ の各画像で19〜22\%SDが向上した.

【結論】画像再構成にて薄いスライス厚の再構成を行った画像に対し 量子ノイズ除去フィルタの使用は被ばく低減に有用である。

\section{MDCTに扔けるノイズ低減処理フィルタの検討} 国立大学法人大分大学医学部附属病院・放射線部 城生朋顕 村上康則，佐藤真理，吉田幸人，高木育也

【目的】当施設では，本年 2 月に32DAS-MDCTが導入され，同年 5 月 にバージョンアップを行った，そのバージョンアップにより，管電 流調整機能 (以下RealEC) とノイズ低減処理フィルタ（以下, 量子 フィル夕)を組み合わせて使用した際，RealECのみを用いた場合よ り，更に低い管電流値での撮影が可能となる機能が付加された。 そ こで, 量子フィル夕を組み合わせて使用することによるノイズ低減 の効果と画質への影響について, 物理的, 視覚的評価を行い, 臨床
使用への有用性を検討した。

【方法】性能評価ファントムを用いて，RealECの設定值であるCT值の 標準偏差值(以下SD)を変化させた場合の量子フィルタによる画質へ の影響および線量低減効果を検討した。

【結果】量子フィル夕を用いることにより，従来の線量より，更に低 い線量での撮影に扔いてもSDをある程度一定に保つことができ，画 質の改善が見られた。

【結論】Thin sliceの画像においても，量子フィルタの強さを変化させ ることによりノイズの少ない画像を得ることが可能となった。ま た，量子フィルタとRealECを組み合わせて使用することにより，， イズ成分を増加させることなく，低線量での撮影が可能となったた め，被ばく線量低減にも寄与するものと考える。

\section{$277 \mathrm{CEV}$-CPRによる血管狭窄率の計測}

(株)日立メディコ・CTマーケティング統括部 高木 博

【目的】マルチスライスCTにより高分解能, 高時間分解能な画像が得 られ，血管系の明瞭な描出が可能となっている。 それに伴い血管径 や狭窄率等の定量的な評価を行うアプリケーションソフトウエアに 対する要求が高まっている. 当社ではCT画像から血管芯線を自動抽 出し，血管CPR (Curved Planar Reconstruction) 表示するシステムを開 発した，血管芯線を軸としたCPR像の360度回転表示により屈曲血管 の狭窄率計測も容易となったので紹介する。

【方法】血管CPR自動表示システムの概要と処理フローを示す。操作 者の最小限作業量で注目する血管をCPR表示することで, 診断や治 療計画, 治療後の効果判定や経過観察をサポートする. 1. 操作者に よる解析血管を含む画像群 (3D画像作成に同等な複数枚の画像)を選 択する. 2. 上記の画像から解析対象の血管の 1 点をマウスでクリッ クする. 解析対象の画像はアキシャル画像を含めたMPR画像又は, 3D画像である．操作者の作業はここまでで以後は自動処理を開始す る. 3. 閾值処理により血管を自動抽出する．閾値は血管の自動抽出 の進行に伴いアダプティブに值が自動設定される．この効果として 造影効果が均一でない場合も血管を確実に描出する．4．自動抽出さ れた血管の中心を通る芯線を指定開始点から頭尾両末端部に向けて 自動的に作線化する。次に芯線を軸としたCPR画像と血管狭窄率を 演算し表示する.

【結果】本システムで注目血管を指定してから芯線の自動抽出は 1 血 管あたり 9 秒前後である。芯線を軸としてCPR像を 360 度回転する ことで屈曲部血管の狭窄部も容易に確認でき，部位ごとに行われる 閥値のアダプティブ設定されるため, 造影剤のむらに伴う狭窄率計 測への影響も少ない.

278 大口径CT装置Aquilion ${ }^{\mathrm{TM}}$ LBシステムの開発 東芝メディカルシステムズ(株)・CT事業部CT開発部 佐々木富也 松澤洋平，戸村正俊，田口 亘, 内蔵啓幸

【目的】マルチスライスCTは, 短時間に広い範囲を高い分解能で撮影 することができる装置として，臨床現場に広く浸透している．今 回, Aquilion ${ }^{\mathrm{TM}} 16$ 列マルチスライスCT装置で培った技術を基軸に, ガントリの開口径と撮影FOVを大きくしたX線CT装置を開発したの で報告する。

【方法】当社CT装置比で，開口径を $720 \mathrm{~mm}$ から $900 \mathrm{~mm}$ へ広げるため, 大径ベアリングを開発した．最小 $0.5 \mathrm{~mm} \times 16$ 列が撮影できる，16列検 出器をべースに，撮影FOV $(700 \mathrm{~mm})$ を広げた検出器を開発した。ま た，開口径が大きくなったことにより，ガントリ回転の遠心力は $15 \mathrm{G}$ に達する。この遠心力に耐え，かつ低振動を実現した高剛性の ガントリに，高冷却効率で熱膨張による焦点移動が無いX線管球を 搭載した。ささらに，オプションとして汎用性の高いフラット天板を 用意し，多くの臨床現場で使用できる環境を整えた。

【結論】開口径，撮影FOVの大きいX線CT装置を開発した。これに 